\title{
Application of marketing management thinking in our higher education Zhiguo FAN $^{1,}$, , Haijing Chai $^{2, b}$ \\ ${ }^{1}$ School of Management, Tianjin University of Technology, Tianjin 300384, China \\ ${ }^{2}$ School of Management, Tianjin University of Technology, Tianjin 300384, China \\ asky2295128977@163.com, ${ }^{\mathrm{b}} 2295128977 @ q q . c o m$
}

Keywords: Marketing ideas, Higher Education, Management Model

\begin{abstract}
Today's competitive education in our society increasingly fierce competition, especially in higher education. More and more colleges and universities began to apply marketing ideas to the management of higher education in the past, to make itself can survive and grow in a competitive environment.

This thesis is devoted to the research of the application of the marketing ideas in the higher education of our country. Firstly, this paper makes a comprehensive summary of the background, significance and current situation of the research, and demonstrates the possibility and necessity of the introduction of marketing management ideas in Colleges and universities in China. Secondly, this paper analyzes the application of marketing ideas in the management mode of higher education from the perspective of "4P". In the process of the analysis, this paper gives some suggestions and opinions, which provides a marketing strategy for the healthy development of colleges and universities.
\end{abstract}

\section{Introduction}

In recent years, higher education in our country continue to move forward, but in the past due to the impact of long-term planned economy, China's higher education mechanism is still facing enormous difficulties. Run under the planned economy system of higher education in accordance with the socio-economic development plan, all kinds of personnel requirements planning, development plans of higher education, universities and enrollment plan, curriculum and teaching programs, universities and employers of graduates of the distribution plan carried out according to plan integration points graduates process. With the deepening of market economy development, the development process is clear that this is no longer suitable for today's higher education management. China's national policy of family planning has made tremendous achievements in recent years, the number of declining national college entrance examination, which resulted in the enrollment of difficult domestic colleges and universities. With the improvement of domestic living standards, more and more parents choose to send their children to study abroad, which is even more emphasis on the issue of domestic university students. Some colleges and universities professional setting unreasonable, leading to the small number of students to apply, or professional settings and social needs completely derailed, resulting in graduates working hard to find these problems, have made a huge decision conundrum facing university management. In order to continue to strengthen the competitiveness of colleges and universities, many universities have begun to change the traditional concept of the school, the "government-oriented" to "take into account the market-oriented" changes, will use marketing thinking to university management mode, so that their own in the fierce competition victory.

The so-called marketing ideas of "4P" theory is the product (Product), price (Price), channel (Place), promotion (Promotion), university administrators make good use of the right combination of these four, it will be the development of a very important Universities theoretical significance, but also has great practical significance, but be able to cultivate more excellent social talents. 


\section{Literature review}

In recent years, more and more domestic scholars began to study marketing ideas used in higher education, trying to close integration of marketing ideas and university management mode on and solve the difficulties faced by universities today. Zou Qiang discussed prospects of higher education management applications in China in 1999, in his book China's higher education marketing strategy; Min Weifang in the Operation Mechanism of Higher Education, a book also mentioned the development of Higher Education in China marketing ideas; Yuan Guohua, Chen Xinyan the characteristics of higher education marketing ideas were summarized, it focuses on a number of characteristics and marketing Implications of Higher Education of Customer marketing, marketing mix, marketing functions and other aspects; Shi ultra is even more studied marketing ideas application of management in the private school, private colleges and universities of our country put forward practical recommendations. Based on previous studies, the research focuses on marketing ideas of "4P" theory of management in higher education, the marketing of the product, price, place and promotion theory applied to operators and Universities among management, further analysis of the use of the depth of marketing ideas.

\section{"4P" theory in Higher Education}

\section{Higher Education Product}

Modern Marketing believes that products are those able to provide to the market, some people used to meet the desires and needs of anything, including the core product, tangible products and additional products. Core products, refers consumers to buy a product to pursue interests, it is something the customer to really buy. As parents of the students to spend a certain amount of money to send their children to school, and their purpose is to let the children learn in college really useful skills, capable of both ability and integrity, to meet the needs of society. Thus the core product can be defined as college students to provide quality educational services, it is not only represents only a diploma, but to improve students' comprehensive ability. Tangible product, target market identification means tangible supplies. Under the condition of market economy, the school needs to provide graduates to the society, so students are the core products of the University of the material manifestation, if colleges and universities can provide qualified staff to the community, then the competitiveness of the university will be greatly enhanced. Additional products, the benefits of all the additional services acquired when people buy the product. Students receive quality education at the same time, if you have a beautiful campus environment, a strong learning atmosphere, first-class living services, the learning power will greatly strengthen, these are the additional products in Colleges and universities. The product of higher education is the organic combination of the three, and the core product is the key, the tangible product is the main body, the additional product is the essential condition, the three are mutually dependent, each other is the condition, is indispensable.

In order to improve the quality of the "product", first of all, the university should improve the professional quality of teachers, teacher selection training, knowledge of teachers, and regular evaluation of teachers, teaching and performance evaluation of teachers; secondly, universities should set in Social Research on professional, reasonable arrangements for professional enrollment, teaching should be more close to the actual, close to the needs of society, the combination of theory and practice, not only focus on the one hand, at the same time to keep pace with the times, the rapid development of today's society, we should firmly grasp the needs of society, good convergence of talent and social needs of the society, pay attention to the cultivation of talents of all-round development; finally, the university should try to provide the hardware equipment, to create a good learning atmosphere, students living atmosphere, encourage innovation, create a harmonious, beautiful, strong learning Atmosphere of the campus environment. When the University's "product" has a high quality, the competitiveness of colleges and universities will greatly enhance.

\section{"Price" in higher education}

Under market economic conditions, any unit shall make appropriate price for the production or 
operation of the product. This is because the price is the main factor that affects the market demand and purchasing behavior. If the enterprise to develop the appropriate price, you can expand sales, improve market share, increase profits. For a long time, the "price" in higher education, namely, the charging standard, is formulated by the education department, the school can not be independent pricing, this traditional pricing model, so that colleges and universities can not give full play to the price of the most flexible adjustment of economic leverage, to achieve the optimal allocation of resources. In recent years, this kind of situation has a certain degree of improvement, the University in the pricing of a certain degree of autonomy, so the university should take advantage of the price of this leverage to achieve their long-term development.

The education resources of our country are limited, so how to develop the standard of the university is a very difficult problem. In the formulation of charges, the first consideration of the cost of education, the school should not be less than the cost of education, so the correct estimation of education costs; second, taking into account other colleges and universities in the same area, while the price level and residents of the region, if the price is too high, it will affect the students in a certain extent, although it has a certain degree of independent pricing, but should be reasonable pricing. Even for some outstanding or exceptional circumstances, students can take the form of a bonus and funding.

\section{"Distribution" in Higher Education -- employment channel}

Only through a certain marketing channels, through the physical distribution process, in the appropriate time and place, with the appropriate price to the majority of consumers, the Enterprise production of products can achieve corporate marketing objectives. In the planned economy era, the employment of college students is assigned by the national unity, the University and the students need not worry about the employment problem. But after entering the market economy, the state is no longer allocates, college graduates entering the job market in the implementation of "two-way selection, self employment". Therefore, colleges and universities have responsibility and obligation to out your product sales. The distribution of the university is to solve the problem of the employment of graduates. Enterprise distribution products to establish a distribution channel system, the school to solve the problem of the employment of students, but also to establish their own distribution channels system. Therefore, colleges and universities can learn from the distribution channels of enterprise products, and establish direct sales channels and indirect sales channels. Direct sales channels are set up by the school students' employment agencies, from the employment agency widely contact with the employer to arrange employment of college graduates; on the other hand, indirect sales channels is the employment agency to work with the talent market or talent intermediary organizations, to help students achieve employment, do a good job in the employment of students.

\section{"Promotion" in Higher Education -- propaganda work}

Promotion is the enterprise through a certain way, the product or service information to the target customers, thereby causing interest, to promote the purchase, to achieve a series of business product sales activities. Under the system of planned economy, colleges and universities, in the past a long period of time of enrollment and employment by the state issued a mandatory plan. Now, however, by the school is responsible for the recruitment and employment, related to the survival and development. Therefore, colleges and universities to promote their own... The promotion of university is to introduce the "product" to the public, to strengthen the communication between the public and the public. The promotion of enterprises has four ways of advertising, marketing, sales promotion and public relations. Colleges and universities can take three ways of advertising, marketing and public relations. Colleges and universities in the relevant media advertising, the introduction of school enrollment information and graduates of the supply of information, the introduction of the school's excellent environment and good life, learning conditions, the introduction of efficient and high quality service, so as to attract the attention of the public, to stimulate their interest. College personnel to sell is to send admissions officers to the various schools, and the majority of students to face the exchange of direct, a variety of ways to introduce the advantages and characteristics of the school. School promotion should be based on the image of 
the school, establish a good image in the eyes of the public. At the same time, the school should hold many forms of public relations .Activities, in public activities to display the school education concept, the school teaching, life, management, price, student employment and other aspects of the advantages and success, in order to win public recognition. Only the university has a better reputation, colleges and universities in the fierce competition will be successful.

\section{Summary and Outlook}

Through the analysis of the "4P" theory in Colleges and universities, we can realize that the marketing idea is not only suitable for the management of enterprises, but also plays an important role in the management and development of colleges and universities. In the present university management, the early awareness of marketing ideas in the importance of higher education, the more early to take measures to seize the opportunity, make the development of colleges and universities more on a floor. The management of the university should pay attention to the quality of the students, develop a reasonable fee, help students to find a suitable way to obtain employment.

The analysis of this paper is mainly for the influence of the "4P" theory in higher education management application, for the influence of other theories, this paper does not have too much involved, but with the development of social institutions, there will be more and more scholars began to study in this area. The correct application of these theories in practice will have a profound significance to the education of our country.

\section{References}

[1] Hurford,Kate. Higher education update. Engineers Australia, v 76, n l, January,2004.

[2] Liguo LI. What is the key to the comprehensive reform of higher education[ $\mathrm{E} B$ / O L ]. 2014-08-12. http://edu.gmw.cn/2014-08/12/content_12485822.html.

[3] Ross A, Bruce D. Teacher self-assessment:A mechanism for facilitating professional growth [J].Teaching and Teacher Education, 2007, 23 (2).

[4] Belyaeva, M. Education quality problems arising at time of University reform. Standarty Kachestvo, n 4,2002

[5] Michael. What is strategy. Harvard business review.2009 